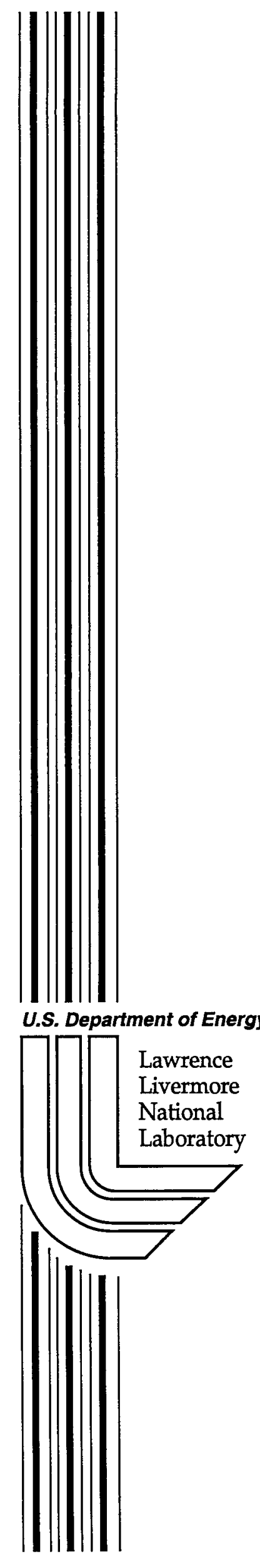

Preprint

UCRL-JC-148426

\title{
Reminiscing About the Early Years of the X-Ray Laser
}

\author{
J. Nilsen
}

This article was submitted to

$8^{\text {th }}$ International Conference on X-Ray Lasers, Aspen, CO, May 2731, 2002

\section{June 26, 2002}




\section{DISCLAIMER}

This document was prepared as an account of work sponsored by an agency of the United States Government. Neither the United States Government nor the University of California nor any of their employees, makes any warranty, express or implied, or assumes any legal liability or responsibility for the accuracy, completeness, or usefulness of any information, apparatus, product, or process disclosed, or represents that its use would not infringe privately owned rights. Reference herein to any specific commercial product, process, or service by trade name, trademark, manufacturer, or otherwise, does not necessarily constitute or imply its endorsement, recommendation, or favoring by the United States Government or the University of California. The views and opinions of authors expressed herein do not necessarily state or reflect those of the United States Government or the University of California, and shall not be used for advertising or product endorsement purposes.

This is a preprint of a paper intended for publication in a journal or proceedings. Since changes may be made before publication, this preprint is made available with the understanding that it will not be cited or reproduced without the permission of the author.

This report has been reproduced directly from the best available copy.

Available electronically at http://www.doc.gov/bridge

Available for a processing fee to U.S. Department of Energy

And its contractors in paper from

U.S. Department of Energy

Office of Scientific and Technical Information

P.O. Box 62

Oak Ridge, TN 37831-0062

Telephone: (865) 576-8401

Facsimile: (865) 576-5728

E-mail: reports@adonis.osti.gov

Available for the sale to the public from

U.S. Department of Commerce

National Technical Information Service

5285 Port Royal Road

Springfield, VA 22161

Telephone: (800) 553-6847

Facsimile: (703) 605-6900

E-mail: orders@ntis.fedworld.gov

Online ordering: http://www.ntis.gov/ordering.htm

\section{OR}

Lawrence Livermore National Laboratory

Technical Information Department's Digital Library

http://www.llnl.gov/tid/Library.html 


\title{
Reminiscing about the early years of the X-ray laser
}

\author{
Joseph Nilsen \\ Lawrence Livermore National Laboratory, Livermore, CA 94551-9900
}

\begin{abstract}
To put the development of the X-ray laser in historic context this paper presents some of the motivation and history of the development of the X-ray laser from the perspective of a scientist at Lawrence Livermore National Laboratory where the first X-ray laser was demonstrated in the early 1980's using a nuclear device as the driver.
\end{abstract}

In the middle of the 1970's there were many papers being written about X-ray lasers. One paper written by George Chapline and Lowell Wood from Lawrence Livermore National Laboratory (LLNL) was published in Physics Today [1]. In that paper they looked at many of the then current X-ray laser ideas and suggested that Xray lasers would have far-reaching impacts on biology, chemistry and crystallography. They suggested that X-ray lasers could someday be used to resolve the structure of molecules.

The worldwide community was already conducting laser-driven plasma experiments with the hope of producing an X-ray laser. This Physics Today paper suggested that one of the most promising laser schemes was to lase at $5 \AA$ on the $n=3$ to $\mathrm{n}=2$ transition in $\mathrm{H}$-like $\mathrm{Kr}$. This is analogous to the $\mathrm{C}$ VI laser later demonstrated at $182 \AA$ [2], but at much higher $Z$. They suggested that a series of psec lasers could be set up to illuminate a cylindrical target from the side with a timing offset between the lasers so as to establish a traveling wave geometry. They acknowledged that current lasers could not yet achieve these goals. The cover page of the article shows the JANUS target chamber and says that X-ray laser experiments were planned using this large ICF laser. Ironically, more than 20 years later a low energy beam of JANUS was used to provide the pre-pulse for the first LLNL experiments to use the combination of a nsec pre-pulse and psec main pulse to drive an X-ray laser with less than 10 joules of energy.

While some groups were seeing signs of gain, one of the first published papers that looked promising was the 1977 paper [3] by Ilyukhin and colleagues from the Lebedev Institute who saw a signal near $600 \AA$ that they thought could be coming from a Nelike $\mathrm{Ca}$ laser on a $3 \mathrm{p}-3 \mathrm{~s}$ transition. Many papers were written about potential Ne- 
like X-ray lasers on these transitions and seven years later LLNL demonstrated the first laboratory $X$-ray laser in Ne-like Se on these transitions [4].

In the early 1980's the news media took notice of the X-ray laser effort because of a new application that would eventually be the primary motivation for X-ray laser research in the United States. In a 1981 Aviation Week article [5] Clarence Robinson wrote that scientists from LLNL had made a breakthrough in laser technology by demonstrating a compact laser device pumped by $\mathrm{X}$-rays from a small nuclear detonation.

At LLNL the early 1980's was an exciting time for the X-ray laser program. LLNL was developing a large $X$-ray laser program to address the challenge presented by President Reagan to develop a missile defense system, know as "Star Wars" or SDI. As part of this program [6,7] LLNL did succeed in demonstrating the first X-ray laser in the early 1980's using a nuclear explosion to drive the X-ray laser. Later the laboratory effort succeeded in demonstrating the Ne-like Se laser on Novette [4].

Reading a 1997 article [8] written by E. N. Avrorin and colleagues at Chelyabinsk70 it is clear that the Soviet Union also took a strong interest in the X-ray laser. In this article they describe how the Soviet Union initiated a program to understand $\mathrm{X}$-ray laser physics and evaluate the feasibility of making an X-ray laser with the characteristics reported in the Aviation Week article. This article reports that experiments were carried out in 1987 using nuclear explosions that successful produced $\mathrm{X}$-ray lasers with about $20 \mathrm{~kJ}$ of output at $39 \AA$ and $100 \mathrm{~kJ}$ of output at a wavelength of $28 \AA$.

Clearly the competition between the United States and the Soviet Union was a significant driver in the development of the X-ray laser.

With the end of nuclear testing in 1992 the X-ray laser program at LLNL ended. However many codes, materials, diagnostics, and other tools were developed as part of this program as discussed briefly below. The legacy of this phase of X-ray laser development continues today.

At LLNL the Nova 2-beam facility was funded by the Defense Sciences Department to help understand $\mathrm{X}$-ray laser physics and more than a decade of research was conducted. X-ray laser imaging was developed at Nova along with greatly improved multi-layer optics that allowed one to build interferometers and other advanced imaging diagnostics. In addition, a tabletop X-ray microscope was developed that achieved $10 \mu \mathrm{m}$ spatial resolution using Fresnel zone plates that worked with an 8

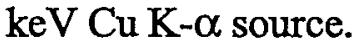

The X-ray laser program required a new level of understanding and measurements of the atomic physics of highly charged ions. The electron-beam ion trap (EBIT) was developed and built at LLNL to address this need. EBIT can now measure any ionization stage of any ion with unprecedented accuracy.

Designing X-ray lasers required more complex atomic models and kinetics codes. Meeting this challenge required greatly improved atomic physics codes such as YODA 
and kinetics codes such as XRASER. With XRASER one could calculate the gain including detailed radiation transport to model trapping and photo-pumping effects.

Many advances took place in developing new materials. For example, aerogel technology took a leap forward with the creation of super-light silica aerogels with densities as low as $1 \mathrm{mg}$ per $\mathrm{cc}$ and the production of organic aerogels.

More details of this legacy can be found in two LLNL documents [6,7] that can be accessed directly from the internet. To summarize, some of the achievements of the Xray laser program include the following: the first laboratory X-ray laser; super light aerogels; advanced plasma kinetics and atomic physics codes; greatly improved diagnostics; the electron-beam ion trap (EBIT) for atomic physics measurements; new digital mammographic techniques; high-resolution $\mathrm{X}$-ray microscopes using zone plates; advanced multi-layer X-ray optics; and the demonstration of the world's shortest wavelength, highest energy laser.

\section{ACKNOWLEDGMENTS}

Work performed under the auspices of the US Department of Energy by the University of California Lawrence Livermore National Laboratory under Contract No. W-7405-Eng-48.

\section{REFERENCES}

1. G. Chapline and L. Wood, "X-ray lasers, "Physics Today, pp. $40-48$ (June 1975).

2. S. Suckewer, C. H. Skinner, H. Milchberg, C. Keane, and D. Voorhees, "Amplification of stimulated soft-X-ray emission in a confined plasma column," Phys. Rev. Lett. 55, 1753-1756 (1985).

1. A. A. Ilyukhin, G. V. Peregudov, E. N. Ragozin, I. I. Sobel'man, and V. A. Chirkov, "Concerning the problem of lasers for the far ultraviolet $\lambda$ approximately $500-700 \AA$," JETP Lett. 25, No. 12, 535-539 (June 20, 1977).

4. D. L. Matthews, P. L. Hagelstein, M. D. Rosen, M. J. Eckart, N. M. Ceglio, A. U. Hazi, H. Medecki, B. J. MacGowan, J. E. Trebes, B. L. Whitten, E. M. Campbell, C. W. Hatcher, A. M. Hawryluk, R. L. Kauffman, L. D. Pleasance, G. Rambach, J. H. Scofield, G. Stone, and T. A. Weaver, "Demonstration of a soft x-ray amplifier," Phys. Rev. Lett. 54, 110 - 113 (1985).

5. Clarence A. Robinson, Jr., "Advance made on high-energy laser," Aviation Week \& Space Technology, pp. 25-27 (February 23, 1981)

6. J. Nilsen, "Legacy of the X-ray Laser Program," Lawrence Livermore National Laboratory report UCRL-LR-114552 (August 6, 1993) See also http://www.llnl.gov/tid/lof/documents/pdf/222506.pdf

7. J. Nilsen, "Legacy of the X-ray Laser Program," Lawrence Livermore National Laboratory report UCRL-52000-94-11 in Energy \& Technology Review p. 13-21 (November 1994) See also http://www.llnl.gov/etr/11.94.html or http://www.llnl.gov/etr/pdfs/11_94.2.pdf.

8. E. N. Avrorin, V. A. Lykov, P. A. Loboda, and V. Yu. Politov, "Review of theoretical works on X-ray laser research performed at RFNC-VNIITF," Laser and Particle Beams 15, 3 -15 (1997). 